\title{
Civic Education Challenges in Dealing with ASEAN Economic Community
}

\author{
Warman \\ Faculty of Teacher Training and Education \\ Universitas Mulawarman, \\ Samarinda, Indonesia \\ cahaya.warman@gmail.com
}

\begin{abstract}
This paper explains the character of civic education in ASEAN Economic Community (AEC) scope in Indonesia as the background of Indonesian history from colonialism era to independence era that can make different rules based on each era. Several problems in implementing civic education in Indonesia are as follows: (a) learning activity gives more knowledge but less application, (b) Some teachers are not able to manage classroom effectively (c) Civic education material and time allocation are not balance, (d) Civic education in Indonesia can make negative effect for learners' perceptions, (e) Some teachers still use the conventional model, (f) Teachers' activities are more dominant than learners'. The role of civic education in the face of ASEAN Economic Community (AEC) are (a) increasing awareness and sense of nationalism to local products; (b) proposing an appropriate regulation, such as obliging every foreigner working in Indonesia to be able to speak Indonesian and obliging investment in rupiah; (c) maintaining an independent attitude and active foreign policy and not fixated on intra-ASEAN trade; (d) promoting and introducing Pancasila economic system in Indonesian economic condition.
\end{abstract}

Keywords-Civic education, ASEAN Economic Community

\section{INTRODUCTION}

ASEAN Economic Community (AEC) can open wider market access and encourage economic growth to increase prosperity, and to strengthen regional competitiveness in the face of global and regional competition. On the other hand, the enactment of AEC also opens up opportunities as well as a tough challenge in employment and economic life, so one important factor in dealing with the AEC is to prepare skilled workers that has capabilities that can be synchronized with the capabilities of workers from other countries.

Education as a platform to improve the quality of competitive human resources in the nation's development. In the opening of the 1945 Constitution, the fourth paragraph states "educating the nation's life", which indicates that education is one of the most important aspects of development. The statement was supported by the President of the Republic of Indonesia Susilo Bambang Yudhoyono in his speech on national education day on 2 May 2013 asserted that education is the provision of the nation's progress.
The AEC issue if associated with Civic Education, illustrates that the challenges of economic competition affect the education system, especially Civic Education. Therefore, the civic system must anticipate the change of life, and be ready to face the $\mathrm{AEC}$ with strategic steps to actualize the relevant national identity in all ages.

As agents of social change, Civic Education in today's era of globalization is required to be able to play it roles dynamically and proactively. Its existence is expected to bring significant changes and contributions for the nation, both at the theoretical and practical intellectual level. In addition, the existence of Civic Education is expected not only as a process of cultivating moral values to fortify people from the negative excesses of globalization, but the most important is how the moral values that have been inculcated can serve as a liberating force from the crush of poverty, ignorance and socio-cultural backwardness and economy. Based on the background, this paper discusses about the role of Civic Education in facing the ASEAN Economic Community.

\section{A. Problems of Civic Education Implementation}

Article 37 paragraphs (1) and (2) in the Act No. 20 of 2003 on the National Education System affirms that Civic Education is one of the subjects that must be taught in Indonesia at all levels of education from elementary to university [1]. However, the fact is that not all schools are able to give an impression of education meaning including Civic Education. Currently, schools have not been a fun educational place and have not provided meaningful knowledge for learners, but they are more burdening learners with a lot of knowledge, yet less meaningful [2]. This statement relates to learners' understanding of teaching materials, including Civic Education, where learners are able to present a good level of acceptance of the material they receive, but find it difficult to apply the material in everyday life. Reference [3] argue that the system of state life (as the field of Civic Education) is the basic structure for the development of Civic Education. Reference [2] said that learners before receiving learning has an initial concept about various phenomena around them and if new concepts received in the school are related with the initial concept of learners, then the learning will be easy to accept. On the contrary, if the contradiction between the initial 
concept and the new concept occurs, learners will encounter difficulty to take the material as input. Even they tend to refuse, such as pretending not to hear, ignore or leave the class.

The issue is how to find the best approach to convey the various concepts of Civic Education so that learners can use and remember the concept in longer term. Have Civic teachers been able to communicate effectively with learners who are always asking about the reasons of something? How can we open the thinking and diverse insights of all learners so that the concepts they learn can be linked to real life? This is our challenge for teachers, especially Civic Education teachers. The following review presents the problems and challenges of Civic Education teachers in school.

\section{B. Nation of Civic Education Teacher}

Teacher, in the simple sense is the one who gives knowledge to learners. Teacher in the community's view is the person who carries out education in certain places, not necessarily in the formal educational institution, but can also in the mosque, at home and so forth [4]. The word "Civic Education" refers to the subjects of civic education that are required to be taught in schools (the 2006 curriculum / KTSP), with the subject matter concerning the relationship between citizens and the State. The Act No. 20 of 2003 on the explanation of Article 37 paragraph (1) states that the subject matter aims to form learners into people who have a sense of nationality and love of the homeland. Thus, Civic Education teacher is a person who serves to implement and provide knowledge to learners about the relationship between citizens and the State and preliminary education to defend the country so that learners will become individuals who have a sense of nationality and love the country.

\section{RESULT AND DISCUSSION}

The meeting of ASEAN countries in Kuala Lumpur Malaysia on August 2006 agreed to develop the ASEAN Economic Community [5]. The meeting resulted in the declaration of the ASEAN Economic Community, which was signed on November 20, 2007 and the declaration points up ASEAN as a single and international production-based market with free flow element of goods, services, investment, educated labor and more free capital (ditjenkpi.kemendag.go.id). In 2015 the ASEAN countries (NGOs) implemented the ASEAN Economic Community (ASEAN) Cooperation. One of the points of the declaration is the provision of educated personnel. Competition in the AEC will be very tight. However in the free market world of AEC, Indonesia will be flooded by workers and business actors from foreign countries in the ASEAN region. In fact, the size of the human resources of Indonesian people is on average under the human resources of foreigners in the ASEAN region. Without skilled, qualified and professional human resources, it can be ensured the State of Indonesia will only create the labor force, such as laborers, and domestic workers. The same will also be experienced by the nation's business players who will become spectators in the AEC. To create skilled workforce who have high competence, qualification and professionalism, education is needed in order that Indonesia human resources can compete with workers from ASEAN countries.

Civic education is democratic education aiming on preparing critical thinking and democratic civillians through embedding the awareness to the young generations. Democration is a form of life in society that ensure civillians' rights. Civic Education is a subject that focuses on forming civillians who can understand and able to carry out their rights and fulfill their duties as clever, skilled, and sensed Indonesian civillians as mandated by Five Principes (Pancasila) and the 1945 constitution. Civic Education is expected to prepare learners to be strong committed and consistent civillians to defend the Unitary State of the Republic of Indonesia. Unitary state is a country formed on the spirit of nationality and a sense of nationalism among the civillians in building the future together although the civillians are different in their religion, race, ethnic, or class. Civic Education as the civillians moal fortress serves to prevent the impact of ASEAN Economic Community (AEC). In the international world, civillians play role as a group that leads the necessity, broad, and common values to attract the support of the other group. In other words, if this group succeeds in influencing the community to defend the sovereignty in utilizing local product, then the ASEAN Economic Community will not be as threaten to the average and the poor people.

The roles of Civic Education in facing AEC are as follows. The first, role is to improve the awareness and nationalism towards local products. This awareness can be proceed through formal education institution such as school and offices or through indirect socialization such as advertisement and daily terms. The second one is to propose the right law product to create a regulation that is profitable for Indonesia. For example, every foreigner working in Indonesia is obliged to communicate using Bahasa Indonesia. Another example is that assets must be invested in rupiahs. The third role is to uphold free and active foreign policy. Political attitude that has been embraced by Indonesian since the independence day should be maintained and not fixated to intra-ASEAN trading. The fourth role is to promote and introduce the five principles (Pancasila) economy system so that Indonesian economy condition stay fixed. The economy condition based on the 1945 constitution article 33 is described as follows:

I. The economy shall be organized asa common endeavour based upon the principles of the family system

II. Sectors of production which are important for the country and affect the life of the people shall be controlled by the state.

III. The land, the waters, and the natural riches contained therein shall be controlled by the state and exploited to the greatest benefit of the people

IV. The organization of the national economy shall be conducted on the basis of economic democracy upholding the principles of togetherness, efficiency with justice, continuity, environmental perspective, selfsufficiency, and keeping a balance in the progress and unity of the national economy. 


\section{CONCLUSION}

Civic Education in Indonesia backgrounded by long history of Indonesia nation starts from pre- to post-colonialism era. It then continues with the seizing and defending independence era to fulfilling independence era, which results in different conditions and requirements appropriate to times. The general purpose of Civic Education is to provide knowledge and basic ability to learners on relation between civillians and the country also as the preliminary education to defend the country in order to be reliable civillans.

Various problems encountered in implementing civic education in Indonesia are as follows. (a) More schools burden learners by providing plenty education, but less meaningful. Learners are able to present good recitation rate to the lesson given, yet they encounter difficulty to apply the materials in their daily life. There are still some civic education teachers who are unable to manage the class effectively. The comparison between lesson and time allocation is unbalanced. The existence of Civic Education on the determination of the graduation had negative perceptions on learners, parents, and some teachers. Some Civic Education teachers focus more on final examination score as their teaching target, still use monotonous conventional model, and are dominated than the learners. As the result, teachers often neglect the process of fostering the value, attitude, and behavior order, and in turn, civic education is not considered as civillians coacing subject that pushes on the awareness of rights and duties rather than a boring and saturated subject.

The roles of civic education in confronting ASEAN Economic Community (AEC) are as follows: (a) to improve the awareness and nationalism towards local products; (b) to propose the right law product to create a regulation that is profitable for Indonesia; (c) to uphold free and active foreign policy, in which political attitude that has been embraced by Indonesian since the independence day should be maintained and not fixated to intra-ASEAN trading; (d) to promote and introduce the five principles (Pancasila) economy system so that Indonesian economy condition stay fixed.

\section{REFERENCES}

[1] Depdiknas, Undang-Undang Sistem Pendidikan Nasional No. 20 Tahun 2003, Jakarta: Depdiknas, 2003.

[2] M. Takwin, Problem dan Tantangan Pembelajaran PKn di Sekolah, 2011 retrieved from http://tanjungpelayar.blogspot.co.id/2011/04/problemdan-tantangan-pembelajaran-pkn.html, accessed on September $20^{\text {th }} 2016$.

[3] A. Suryadi, and Somardi, Pemikiran ke Arah Rekayasa Kurikulum Pendidikan Kewarganegaraan, Bandung: CICED, 2000.

[4] S. B. Djamarah, Guru dan Anak Didik Dalam Interaksi Edukatif, Jakarta: Rineka Cipta, 2005

[5] Asean Economic Community Blueprint, retrieved from http://asean.org/wp-content/uploads/archive/5187-10.pdf 